\title{
Consideration of tobacco dust as organic amendment for soil: A soil \& waste management strategy
}

\author{
Sarah Shakeel \\ Department of Environmental Sciences, Kinnaird College for Women Lahore, Pakistan 54000
}

Email address:

sarahshakeel@hotmail.com

\section{To cite this article:}

Sarah Shakeel. Consideration of Tobacco Dust as Organic Amendment for Soil: A Soil \& Waste Management Strategy. Earth Sciences. Vol. 3, No. 5, 2014, pp. 117-121. doi: 10.11648/j.earth.20140305.11

\begin{abstract}
Soil is non-renewable reserve that has high frequency of contamination and very low rate of replenishment in this environment. Immense food requirements have evolved the compelled usage of chemical fertilizers to have optimum crop leaf area in minimum time scale that have devastating impacts on biological, physical and chemical properties of the soil. Organic farming is an ultimate solution for the soil management. Tobacco dust an agro-industrial waste can be applied to the soil to recycle essential nutrients such as nitrogen $(\mathrm{N})$, phosphorous $(\mathrm{P})$ and potassium $(\mathrm{K})$ back into the soil that plant has taken up from the soil. Tobacco dust is rich in nitrogen $(\mathrm{N})(2.35 \%)$, potassium $(\mathrm{K})(1.95 \%)$ and phosphorous $(\mathrm{P})(937 \mathrm{ug} / \mathrm{g}) \mathrm{which}$ can provide essential nutrients to the soil and plant. It has abundant quantity of organic content that exceeds the micro and macroorganism movement in soil which further increases the porosity of the soil; increase the infiltration of the oxygen. This study has indicate that tobacco dust increases the $\mathrm{pH}$ of the soil, maintain the electrical conductivity (EC) that does not leads to the salinity of the soil. Further it also increases the nitrogen $(\mathrm{N})$ content in various vegetable, house-plants and wheat straws and increases the biomass content and average survival rate of the tomatoes. It's a good insecticide; prevent the insects and other viruses such as Tobacco mosaic virus that are detrimental for the crops such as pepper, cucumber that shows light and dark green, crinkled, puckered leaves. Furthermore it's an eco-friendly management strategy for soil, environment and human health that does not generates pollution however it reduces the organic waste.
\end{abstract}

Keywords: Insecticide, Organic Fertilizer, Organic Farming, Soil Management, Soil Nutrients, Sustainable Agriculture, Tobacco Dust

\section{Introduction}

The soil leached out its basic as well as necessary elements during long term plantation and crop production (Abbott L.K, 2007). This circumstance mainly requires a well suited soil management system and strategies which can conserve the soil elementary nutrients moreover enhance the capacity of soil productivity for future benefits (Cercioglu and Okur, 2010). For that purpose many artificial or synthetic fertilizer were used by farmers to cultivate the field completely in fewer span of time. But that will surely cause environmental degradation in any manner same as the environmental deterioration was happen during the green revolution. In the green revolution era, studies have showed that enormous growth of crops yield was recorded with much new variety of plants due to the application of many non-natural fertilizers that caused damage to soil, air, ecological possessions and most importantly the human health (Ganiger et al., 2012).
Author Diacono and Muntemurr, (2009) have aroused the importance of the resource with identifying the complexity of degradation rate of soil. Soil that is a non-renewable resource and its deterioration leads towards desertification with having very lower rate of replenishing. That has resulted many vast problems such as climate change adversity and green house effects.

Gopinath et al., (2009) have mentioned in their research work that sustainable agriculture is the resolution of all the concerns that are happening in the today's world. Author has mentioned that organic farming is a tool for a sustainable agriculture that leads to better environmental conditions. It is a complete integrated system entirely free from chemicals that combines all the factors of environment i.e. soil, air, water, flora and fauna. All these factors better in condition will produce biological system that will be alive and it will 
run a complete sustaining ecosystem. Moreover author Abbot and Murphy, (2007) stated the same ideas as above that sustainable agriculture will be attain if the soil has the fertility to grow crops. The soil fertility is the ability of soil to nurture the plant by providing physical, chemical and biological needs for the growth. Thus sustainable agriculture is to maintain sustainably a resource with its use without its loss.

\section{Objective of This Review}

To assess and analyze the optimum effects of agroindustrial waste i.e. Tobacco Dust as organic amendment to soil and plants that will whether ultimately improve the soil quality and may give a more convenient way of disposing the agro-industrial waste and resolving its disposal issue. Thus knowing the effectiveness of the amendment to the soil's physical, chemical and biological soil quality indicator.

\section{Agro-Industrial Waste}

Adediran et al. (2004) has stated the actual significance of agro-industrial waste that is the surplus, unused, remaining material generated from an agricultural material that is handled in agricultural linked industry which can be used as an amendment to the soil and plants. The author also believed that it is mainly an excellent choice to discontinue commercial, chemically synthesized fertilizer for the green leaf. Another author has stated that tobacco solid waste is classified as agro-industrial waste. It can be used as organic amendment for soil and plants. This implementation will leads to fertility of the soil as well as the adoption of the green farming strategy with sustainable agriculture (Cercioglu et al. 2012).

\section{Tobacco Dust}

Tobacco is a green plant that has importance to the cigarette companies (Kayikcioglu and Okur, 2011). It is adopted to grow in warm climate then it is cultivated, dried, and grinded and the fine tobacco powder has been used in different cigarettes, cigar and pipes (Jacobs, 1997).

Pakistan is home to a number of varieties of tobacco namely Flu Cured Virginia, Light Air Cured, Light Sun Cured, Dark Air Cured, Semi Oriental and Dark Sun Cured. Food and Agriculture Organization (FAO) figures stated that tobacco was cultivated on nearly 50,000 hectares in the year 2009 (Stull, 2009).

Author Cercloglu and Okur, (2010) has mentioned that the tobacco dust that generated from a cigarette industry has not used directly or can use on other purposes. The cigarette companies have to pay its disposal cost. These types of agroindustrial waste are burned or delivered to the incinerated plants for the reduction of the waste pile.

\section{Chemical Composition of Tobacco Dust}

Tobacco dust is rich in nitrogen $(\mathrm{N})(2.35 \%)$, potassium $(\mathrm{K})$ $(1.95 \%)$ and phosphorous (P) $(937 \mathrm{ug} / \mathrm{g})$ (Chaturvedi et al. 2008). It provides sufficiently nitrogen (N) to the newly grown plants. It's a great source of nitrogen $(\mathrm{N})$ for the container grown- houseplants (Mikkelsen 2003). Tobacco dust has high organic carbon that is high organic matter and have low toxic element content that make it favorable for the application on soil (Adediran et al. 2004).

Tobacco dust is a by-product of many cigarettes company during the manufacturing process. Compared with other plant material wastes, tobacco dusts contained higher levels of nitrogen $(\mathrm{N})$, potassium $(\mathrm{K})$ and iron $(\mathrm{Fe})$ as mentioned by author Adediran et al. 2003. This may be due to the cutting machine used in process but this tobacco dust may be applied to iron depleted soils.

Briski et al. (2003) has signifies the chemical content of tobacco dust that its aqueous fraction has a TOC concentration above $200 \mathrm{mg} / \mathrm{L}$ and therefore it cannot be disposed of in a sanitary landfill. Furthermore, it contains nicotine, which makes it hazardous.

Table 1. Physiochemical Composition of Tobacco Dust.

\begin{tabular}{lll}
\hline Sr. No. & Parameters & Values \\
\hline 1. & Moisture Content & $7.7 \%$ \\
2. & $\mathrm{pH}$ & 5.69 \\
3. & Ash & $35.4 \%$ (dry) \\
4. & Total Nitrogen ( Kjeldahl) & $2.38 \%($ dry $)$ \\
5. & Carbon/Nitrogen ratio & 15.1 \\
6. & Phosphorous & $0.5 \%($ dry $)$ \\
7. & Calcium & $3.7 \%($ dry $)$ \\
8. & Magnesium & $0.55 \%$ (dry) \\
9. & Potassium & $0.4 \%$ (dry) \\
10. & Nicotine & $1.50 \%$ (dry) \\
\hline
\end{tabular}

Source: Sponza. D. T., "Toxicity Studies in a Tobacco Industry Biological Treatment Plant”. Journal of Water, Air, and Soil Pollution, 134: 137-164 (2002).

\section{Efficiency of Tobacco Dust in Agriculture}

Organic matter and its amendment to the soil increase the nutrient values of the soil. The application of the organic amendments greatly effects electrical conductivity of the soil in positive aspects (Gulser et al. 2010). As the tobacco dust has high organic content that improves the soil chemical structure by improving the ions structure, electrical conductivity and nutrients level furthermore it also physically improve the soil with refining the water intake capacity, water holding capacity (Aggelides and Londra, 2000). The tobacco dust decreases the soil bulk density whereas its increases the organic carbon content (OC), porosity and infiltration of the soil (Candemir et.al 2012). Author Candemir and Gulser (2010) has stated that the provision of the carbon (C) through the amendment such as tobacco dust 
leads to the facility of the energy sources to the microorganisms in the soil and thus make them energetic in the soil that cause of the aeration source/oxygen delivery into the soil.

Tobacco industries produces large amount of organic wastes during the manufacturing and processing of the cigarettes. The most useful of them are ground part of the leafs. This type of the waste is characterized in high content of total nitrogen and $\mathrm{C}$ : $\mathrm{N}$ ratio $13.5=15.9$. This quality makes it to use it directly on the agriculture. Author also analyzed that nitrogen in the tobacco dust shows high manorial value expressed in terms of high crop yields and degree of its utilization. This organic waste has an advantageous effect on the soil in terms of increasing the soil humus with every increasing quantity of the organic amendments (Jacek C. et.al. 2002).

Another author has manifest that the organic matter is very vital for the soil. Through the organic matter in tobacco dust leads soil to respire and promotes the growth of the plant. The micro and macro-organism activity is stimulated with the organic matter. The soil will be loosened then the oxygen required for the decomposition of the organic matter and for respiration become more sufficient and results in release of the carbon dioxide (Parkin et al. 1996).

Improved aggregate stability by addition of tobacco dust to soils is a result of released plant phenolic acid interactions during the decomposition of residues structural components and increasing microbial activity due to carbohydrates metabolisms (Martens, 2000).

The past researches have shown that soil treated with tobacco dust immediately after tobacco dust has been refused from the cigarette company. But some research has evolved a new prospective that the effect of tobacco dust can be more effective when it is in the form of compost. Author Okur (2007) has indicated that as the tobacco dust contained a high quantity of nicotine in it that makes it somewhat toxic to the soil and to plant as well. The directly use of the tobacco dust may cause harm to the agriculture. Due to the nicotine presence, it decreases the organic carbon transfer to the soil and hence reduces the microbial biomass (Adediran et al. 2003).the best technique for that problem is to compost the tobacco dust that will breakdown the nicotine components and make it less toxic to the soil and plant (Adediran et al. 2004).

Furthermore nicotine by its nature is an insecticide that may protect the plants from insects that cause adverse damage to the crop (Baldwin and Callahan, 1993). Past literature has shown that the application of the tobacco dust to the soil that has alkaline in nature may increase the soil's chemical, physical structure to have fertile soil. Moreover as an insecticide, the tobacco dust has been applied on soil to repel the insects to reduce the harmful effects of insects on the crops. Author Lind A. 2006 has researched that application of the tobacco dust may reduce the ants Lasius Niger nest in the garden, lawn as well as in cropping area. The tobacco dust acted as an insect repellent that transplant the ants and other soil insects that are harmful for the crops to the other sites for nesting.

Author Chaturvedi (2008) has confirmed that in prior researches the application of the tobacco dust as organic amendment provide the nutrients such as high quantity of the nitrogen $(\mathrm{N})$ that is required for the plant growth and carbon content that improves the soil's micro biomass and soil porosity that leads to the high grain yield of wheat. Another author confirmed the above fact with statistics that upon the application of the tobacco dust on the wheat crops, wheat straw increases its nitrogen content from $0.4 \%$ to $0.7 \%$ (Brohi and Karaman 1998). The yield of tomato and its nutritional values are also enhanced by the application of the organic fertilizers as the practical done on tomato nutritional content, its yield, its average time growth by Karaman et al., 2004 as compared with the control one. Author Melchias et al., 2013 has researched that the survival of the tomato was significant due to the effect of tobacco dust amendment over control treatment. The average survival was $96.32 \%$. It also gives fresher biomass of tomato.

From the past literatures (Saltalt.K., et.al.2002) it was confirmed that the addition of the tobacco waste increases the soil essential nutrients in a required amount. The each addition of this organic amendment increases the soil nitrogen and available phosphorous and potassium content. The alkaline soil improved and soil condition and its nutrients concentration both increased for the sustainable crop production without the loss of nutrients. Other author have commented that the addition of the tobacco dust increased the other nutrients such as potassium and magnesium (Bulluck, L.R et.al. 2002). Author also revealed that the tobacco dust increases the nitrogen content $\mathrm{NO}_{3}-\mathrm{N}$ gradually in soil as it get mineralized with the passage of time.

Agrawal et al. (2006) in their study have found beneficial effect of nutrients like nitrogen and phosphorus on plant growth and yield of moong bean. Levizou and Manetas (2000) had observed that a high nutrient level of $\mathrm{N}, \mathrm{P}$ and $\mathrm{K}$ improves the growth in phlomisfruticosa. Thus the improved morphological parameters including increase in height in plants produced on treated soil are due to enhanced nitrogen and phosphorus levels resulting from application of tobaccowaste.

The treatment of soil with the tobacco dust has been studied in past literature that showed the effectiveness of it to soil. The application of the tobacco dust has increased the soil $\mathrm{pH}$ and did not cause negative effects to the soil and plant. Author Cercioglu et al. (2012) has also confirmed that due to the application of the tobacco dust it does not leads to the excess of total salts that may retard the plant production. The application of the amendment does not cause the salinity problems in the soil.

There is evident from the past literature that tobacco dust application may increases the electrical conductivity (EC) in clay and loamy sand soils. It is an important parameter for monitoring the organic matter mineralization (De Neve et al. 2000). In various studies it was revealed that the tobacco dust supplies the higher amount of organic matter to the soil that 
increases the mobility of the microorganism activity and increases the nutrient availability to the plant also. This organic amendment leads to the transformation of the nitrogen content (NO3-N) in soil due to the mineralization of organic matter (Lee et al. 2004).In previous study, EC values in soils were also influenced by the EC values of the organic wastes. The largest increase in EC value was obtained with the tobacco waste application in clay and loamy sand soil at the first sampling time. This indicates that tobacco dust had a more rapid mineralization rate than the other wastes (Candemir. F. Gülser.C. 2010).

Another study has evolved the significance of tobacco dust application on soil for the management practice. The practice showed that due to the chemical nature of the tobacco dust and its nicotine presence make the soil unfit for the insects breeding. That's why in South America the control of Golden Apple snail problem in paddy field and nearby crops was solved due to the application of the tobacco dust. That will reduce the consumption and spray of the extensively damaged synthetic and commercial fertilizer on crops (Tangkoonboribun and Sassanarakkit, 2009). Tobacco dust can be reduced rice damaged by golden apple snail about $14 \%$.The rate of application more than $625 \mathrm{Kg} / \mathrm{ha}$ can be improved rice yield and yield component due to tobacco dust contained of high nitrogen with $1.34 \%$ and high organic matter with $46.65 \%$. The optimum rate of tobacco dust to control golden apple snail was $1562.5 \mathrm{Kg} / \mathrm{ha}$. Iida et al. (1998) used tobacco dust which has nicotine $2.8 \%$ at the rate of $712.5 \mathrm{Kg} /$ ha to killed snail.

The tobacco mosaic virus belongs to the genus tobamorvis and cause severe damage to the crops leads to the financial crises in Turkey. It caused due to the organic waste infected with the tobacco mosaic virus. Its control can only be done by the application of the tobacco dust addition to the soil (Tan et al., 1997). The tobacco dust has high content of organic percentage that increases the $\mathrm{pH}$ of the soil, improves the total porosity and increases the infiltration of the soil Candemir et al., 2012). The tobacco dust affects the $\mathrm{pH}$ of the soil and makes it to increase level, increase precipitation factor and infiltration situation can greatly remove these viruses from the soil.

\section{Conclusion}

Soil needs organic amendments for its fertility. Chemical and inorganic fertilizers may produce positive impacts on soil but it degrades environment in many ways including soil pollution, air pollution, and water pollution if it leached down to water table. The approach of burning or incinerating the organic waste i.e. tobacco dust may cause the ejection of the harmful gases and also the usage of the extra fuel to ignite and burn that waste may consume many resources. The amendment of agro-industrial waste will be cost effective in spite of commercial fertilizer and it contributes towards the waste management. It increases the nutrient availability further it provides the essential nutrients gradually to the soil turn it to fertile and makes it available for the plant when it requires. That's why this strategy is leading to the environmental sustainable approach and protecting our very beautiful environment.

\section{References}

[1] Abbott L.K., Murphy D.V. (2007). What is soil biological fertility? Soil biological fertility - A key to sustainable land use in agriculture, Springer.1-15, ISBN 9781-4020-6619-1.

[2] Adediran, J. A., Mnkeni, P. N. S., Mafu, N. C. And Muyima, N. Y. O., (2004). Changes in Chemical Properties and Temperature during the Composting of Tobacco dust with other Organic Materials, and Effects of Resulting Composts on Lettuce (Lactuca Sativa L.) and Spinach (Spinacea Oleracea L.). Biological Agriculture and Horticulture. 22: 101-119.

[3] Adediran. J.A., Baets. N. D., Mnkeni. P.N., Kiekens. L., Muyima. N.Y.O., Thys. A. (2003).Organic Waste Materials for Soil Fertility Improvement in the Border Region of the Eastern Cape, South Africa. Journal of Biological Agriculture and Horticulture, 20: 283-300.

[4] Aggelides, S.M. and Londra, P.A. (2000). Effects of compost produced from town wastes and sewage sludge on the physical properties of a loamy and a clay soil. Biores.Technol., 71,253259.

[5] Briski.F.,Horgas. N., Vukovic M., Gomzi. Z. (2003).Aerobic Composting of Tobacco Industry Solid Waste - Simulation of The Process. Journal of Clean Techno. Environ Policy, 5; 295 307.

[6] Brohi, A.R. and M.R. Karaman (1998). Determination of the utilization of nitrogen from tobacco dust by wheat crop with $15 \mathrm{~N}$ tracer technique. Tr. J. Agric. For., 22, 593-600.

[7] Candemir. F. And Gulser. C. (2010). Effects of Different Agricultural Wastes on Some Soil Quality Indexes in Clay and Loamy Sand Fields. Journal of Communications in Soil Science and Plant Analysis, 42(1): 13-28.

[8] Cercioglu.M.,Okur.B. (2010).Effects of Tobacco dust and Farmyard Manure on Macro Element Status of Soil and Yield of Grown Lettuce (Lactuca Sativa L. Var. Capitata)..47(3):331-338.

[9] Cercioglu.M., Okur. B., Delibacak. S., Ongum. A. R. (2012). Effects of Tobacco dust and Farmyard Manure on Soil Properties and Yield of Lettuce (Lactuca Sativa L. Var.Capitata). Journal of Communications in Soil Science and Plant Analysis, 43:875-886.

[10] Chaturvedi.S.,Upretil. D.K., Tandon. D.K., Sharma. A., Dixit. A. (2008).Bio-Waste from Tobacco Industry as Tailored Organic Fertilizer for Improving Yields and Nutritional Values of Tomato Crop. Journal of Environmental Biology, 29(5):759-63.

[11] Den eve, S., J. Van De Steene, R. Hartman and G. Hofman. (200). Using time domainreflectometry for monitoring mineralization of nitrogen from soil organic matter. European Journal of Soil Sciences. 51, 295-304.

[12] Diacono, M. andMontemurro., F. (2010). Long-term effects of organic amendments on soilfertility.A review. Agronomy Sustainable Development: 30 401-422. 
[13] Ganiger. V. M., Mathad. J.C., Madalageri. M.B., Babalad. H.B., Hebsur. N.S., Yenagi. N.B. (2012).Effect of Organics on the Physico-Chemical Properties of Soil after Bell Pepper Cropping under Open Field Condition. Karnataka Journal of Agricultural Sciences.25(4): 479-484

[14] Gopinath, K. A., Supradip-Saha., Mina, B. L., HaritPande., Srivastava,A. K. and Gupta, H. S.(2009).Bell pepper yield and soil properties during conversion from conventional to organic production in Indian Himalayas.ScientiaHorticulturae,122 : 339-345.

[15] Gulser. C., Demir. Z., Ic. S. (2010).Changes in Some Soil Properties at Different Incubation Periods after Tobacco dust Application.Journal of Environmental Biology. 31(5): 671-674

[16] Iida, G. B., Relicardo, M. C., Edwi,n F. M., Francisca D. S. \& Angela, T. M. (1998).Molluscicidal acitivity of tobacco dust against brackish water pond snails (Cerithideacingulata Gmelin).Crop protection. 17 (1): 401-404.

[17] Jacobs. M. (1997). From the First to the Last Ash: The History, Economics \& Hazards of Tobacco.A Comprehensive Adult Basic Education Curriculum, 1-112 (Revised 1997).

[18] Karaman, M.R., A.R. Brohi, I. Ali and Akgün Aydeniz. (2004) $15 \mathrm{~N}$ investigation of nitrogen released from tobacco-waste to be utilized by maize crop.IsotopesEnviron.Hlth. Studies, 40, 285-290.

[19] Kayikcioglu. H. H., Okur. N. (2011).Evolution of Enzyme Activities during Composting of Tobacco dust. Journal of Waste Management and Research. 29(11): 1124-1133.

[20] Lee,J.J., R.D. Park, Y.W. Kim, J. H. Shim, D.H. Chae, Y. S. Rim, B.K. Sohn,T. H. Kim and. Y.Kim. (2004). Effect of food waste compost on microbial population, soil enzyme activity and lettuce growth.Biores. Technol., 93, 21-28.

[21] Melchias, G., Saravanan, P., Kumar, S.S., Elizbeth, M. (2013).Effect of Tobacco dust onEnhanced Productivity of Tomato Plant. International Journal of Pharmacy \& Life Sciences (IJPLS).4(4); 2605-2607.

[22] Mikkelsen.R.L. (2003).Using Tobacco By-Products as a Nitrogen Source for Container-Grown Houseplants. Journal of Plant Nutrition, 26:1697-1708 (2003).

[23] Okur, N., Kayikcioglu. H. H., Okur, B., Delibacak, S. (2008). Organic Amendment Based on Tobacco dust Compost and Farmyard Manure: Influence on Soil Biological Properties and Butter-Head Lettuce Yield. Turkey Journal of Agriculture.32; 91-99.

[24] Parkin, T. B., J. W. Doran, and E. Franco-Vizcaino. (1996). Field and laboratory tests of soil respiration.InMethods for assessing soil quality (Special Publication 49), ed. J. W.Doranand A. J. Jones, 231-246.
[25] Sponza. D. T. (2002). Toxicity Studies in a Tobacco Industry Biological Treatment Plant. Journal of Water, Air, and Soil Pollution, 134: 137-164.

[26] Stull. D. D. (2009) "Tobacco Is Going, Going . . But Where?" Journal of Culture \&Agriculture.31 (2): 54-72.

[27] Tan S. H., Nishiguchi M., Sakamoto W., Ogura Y., Murata M.,Ugaki M., Tomiyama M.,Motoyoshi F.(1997). Molecular analysis of the genome of an attenuated strain of cucumber green mottle mosaic virus. Annals of the Phytopathologicial Society of Japan. $63 ; 470-474$.

[28] Tangkoonboribun, R., Sassanarakkit, S. (2009). Molluscicide from Tobacco dust. Journal of Agricultural Science. 1(1):7681.

[29] Candemir, F., Dide, N., Yilmaz, K., Gulser, C. (2012). The effect of tobacco dust application on Tobacco mosaic virus (TMV) concentration in the soil. Zemdirbyste Agriculture, 99 (1); 99-104.

[30] Jacek C, Monika J, Andrzej M, Wojciech O. The Utilization of Tobacco Dust as a Source of Nitrogen for Plant and of Carbon for the Formation of Humus Compounds in Soil. Department of Soil Science. Agricultural University of Poznan. 2002; Proceeding of 10th International Conference of the Ramiran.

[31] Saltalt, K., Brohi, A.R., Bilgli, A.V. (2002). The effects of tobacco waste on the soil characteristics and plant nutrient content of alkaline soil. In proceedings of international Symposium on Desertification, Konya 531-534.

[32] Bulluck LR, Brosius M, Evanylo GK, Ristiano JB (2002). Organic and Synthetic Fertility Amendments Influence Soil Microbial, Physical and Chemical Properties on Organic and Conventional Farms. Appl. Soil Ecol; 19:147160.

[33] Agrawal, S.B., Dheeraj Rathore and Anoop Singh. (2006). Combined effects of enhanced ultraviolet-B radiation and mineral nutrients on growth, biomass accumulation and yield characteristics of two cultivars of vigna radiate L. J. Environ. Biol., 27, 55-60.

[34] Levizou, E. and Y. Manetas. (2001). Combined effects of enhanced UV-B radiation and additional nutrients on growth of two Mediterranean plant species. Plant Ecol., 154, 181-186.

[35] Martens, D.A. (2000). Plant residue biochemistry regulates soil carbon cycling and carbon sequestration. Soil Biol. Biochem., 32, 361-369.

[36] Lind, A., Martin, A, J., Aron, U., Hiiesaar, K., Koskor, E., Lukas, T. (2006). Development and control of mound nests of black garden ants (Lasius Niger) in farmland. Agronomy Research. 4; 269-272. 